\title{
Explaining Internationalisation of Small to Medium Sized Enterprises within the Queensland Food and Beverage Industry
}

\author{
Mitchell Spowart \\ Accenture Australia \\ Level 348 Pirrama Road, Pyrmont \\ New South Wales 2009, Australia \\ Tel: 61-400-745-080 E-mail: mitchell.spowart@accenture.com \\ Rumintha Wickramasekera (Corresponding author) \\ School of Advertising, Marketing and Public Relations \\ Queensland University of Technology \\ GPO Box 2434, Brisbane \\ QUEENSLAND 4001, Australia \\ Tel: 61-7-3864-1560Ｅ-mail: r.wickrama@qut.edu.au
}

Received: October 27, 2011

Accepted: January 30, 2012 Published: March 16, 2012

doi:10.5539/ijbm.v7n6p68

URL: http://dx.doi.org/10.5539/ijbm.v7n6p68

\begin{abstract}
The prevalence of International New Ventures (INVs) has increased during the past twenty years. Nevertheless, to date there has been no general consensus within the literature on an explanation as to the rapid internationalisation of some firms. Do they follow a similar process to other firms that internationalise based on a more 'measured' incremental sequential process of internationalisation. This paper proposes and tests an innovation diffusion model of the internationalisation of small firm INVs and others by drawing on key innovation diffusion models from the literature. The results of this analysis indicate that the synthesised model of export adoption is effective in explaining the internationalisation process of INVs and other firms within the Queensland Food and Beverage Industry. Significantly, the features of the original innovation diffusion models developed in the consumer behaviour literature, which had limited examination within the internationalisation literature, were confirmed. This includes the ability of firms, or specifically decision-makers, to skip stages based on previous experience.
\end{abstract}

Keywords: Internationalisation, Small firms, Innovation diffusion, International new ventures, Stages

\section{Introduction}

An emerging theme in the internationalisation literature is the examination of International New Ventures (INVs) or Born Globals (Rialp, Rialp, Urbano \& Vaillant, 2005). The INV is characterised as being a Small to Medium-Sized Enterprise (SME) that internationalize its operations within a six year period after inception (Oviatt \& McDougall, 1994, 1997). Numerous studies indicate that the rise of INVs is associated with high technology industries (e.g., Bell, 1995; Jones, 1999; Knight \& Cavusgil, 1996; Oviatt \& McDougall, 1994). In these industries, the constant need for innovation and the rapid development of technology is linked to the need for rapid internationalisation (Jones, 1999). However, it has become apparent that the rise of the INV may not be limited to the high technology area and that they may even be found in more traditional industries (Chetty \& Campbell-Hunt, 2004) such as the food and beverage industry.

An even more significant issue is the question of which theoretical framework is the most appropriate for explaining INVs' existence (Madsen \& Servais, 1997), along with other firms that internationalize over a longer period of time. Wide ranging debate exists over the internationalisation process of these INVs, particularly the suitability of established models of internationalisation for explaining the internationalization process of INVs. Some authors have criticised existing staged models due to their incremental and sequential nature (i.e., Knight \& Cavusgil, 1996; Oviatt \& McDougall, 1997). Nevertheless, these criticisms have been made without clearly 
distinguishing between the key differences of the two main stage based approaches: the Uppsala Model and the innovation adoption models. This limitation of the criticisms of stage based models has meant that by implication, the more flexible innovation adoption models, which do not necessarily follow an incremental sequential staged approach, have been discounted as a possible solution for explaining INV internationalisation. Research suggests, however, that these stage based models may provide a promising avenue for explaining INV internationalisation and are worthy of consideration (e.g., Chetty \& Hamilton, 1996; Fan \& Phan, 2007). Nonetheless, many of these arguments remain inconclusive and as such, a clear theoretical framework for explaining INV internationalisation has yet to be proposed.

This paper puts forward a synthesised model of export adoption drawing upon the innovation diffusion models from consumer behaviour and internationalisation schools. Although the models from internationalisation literature have advanced our understanding of the internationalisation process, they have excluded some key attributes of the original consumer behaviour models. By combining the approaches of both schools of thought, in particular, ensuring that the salient features of the initial consumer behaviour innovation diffusion model are not neglected in re-evaluation, the richness of the model can be improved.

\section{Literature Review}

It is generally accepted that the study of the process of firm internationalisation and export development encompasses two schools of thought: the Uppsala Model and the innovation adoption models (Andersson \& Wictor, 2003). The basic premise of both models is that they comprise a varying number of stages (Andersson \& Wictor, 2003). These models are important in a number of respects. Firstly, within the internationalisation literature, they are some of the most widely reported models, although a single unifying model is yet to emerge. Secondly, for many firms, exporting is the most common mode of international market entry (Clark, Pugh \& Mallory, 1997) and these models explain the process involved in this type of market entry. This is significant given that exporting is the form of internationalisation favoured by governments due to the well established economic benefits that accrue to the country, regions, and the firm (Department of Foreign Affairs and Trade, 2008). However, in recent years these models have been criticised for their inability to explain the internationalisation of Born Globals or INVs (Coviello \& McAuley, 1999). In order to understand these issues, whilst being mindful of the limitations imposed by the length of the paper, only a review of the key innovation diffusion models will be presented below. This will subsequently be followed by a review of the emerging literature on INVs.

\subsection{Innovation Adoption Models}

Innovation diffusion models explain the process firms go through in adopting the innovative practice of exporting. Initially derived from consumer behaviour literature, these models illustrate the sequences of stages firms progress through in making the decision to export. The following discussion will review the key innovation diffusion models from the schools of consumer behaviour and internationalisation.

Although the initial work on innovation diffusion by Rogers (1962) is from a consumer behaviour perspective, and does not directly consider the internationalisation process, it provides the conceptual framework for numerous studies in the internationalisation literature. Rogers's (1962) Theory of Innovation Adoption is one of the first major works utilised to clearly define and explain the adoption process as highlighted by Lim, Sharkey and Kim (1991). Rogers argues that the adoption process is in essence a mental process of learning. Initially the individual, or adopting unit, hears about the innovation and then continues to receive information regarding the innovation. From this point, the individual makes numerous interrelated decisions regarding the new innovation and whether it will be adopted or not (Rogers, 1962). To effectively apply this conceptually, Rogers divided the adoption process into five stages: awareness, interest, evaluation, trial, and adoption (Table 1). In developing this model, however, Rogers clearly indicated that the adoption process need not be a five stage process. It could be more or less, since the number of stages in the sequence is a reflection of their usefulness in explaining the process, rather than a sequence of stages that are strictly adhered to in actual adoption (Rogers, 1962).

\section{Insert Table 1- here}

In explaining the adoption process, Rogers argued that innovation adoption was not a type of impulse behaviour, but rather a behaviour that usually took time to complete. In addition, upon reflection, Rogers raised two additional salient points with regards to the model. Firstly, he highlighted that at any stage in the adoption model there is the possibility for rejection of the innovation. If rejection occurs after final adoption, it is deemed as 'discontinuance'. The second point Rogers emphasised was the adopting unit's ability to skip stages within the model. This behaviour manifests typically in late adopters within the trial stage of the adoption process (Rogers 1962). 
Another model that examines the adoption process from the perspective of marketing/consumer behaviour is the Robertson (1971) model. A key feature of this model is the number of stages it encompasses in comparison to many other innovation diffusion models. Robertson's model consists of eight stages that the individual or adopting unit passes through to adopt an innovation. Robertson (1971) highlighted, however, that there is no specified number of stages prescribed for a innovation diffusion model. Importantly, he suggested that the upper limit on the number of stages is dependent on the ability of the researcher to draw clear distinctions between the stages and to the extent that they reflect the real world. Although the Robertson (1971) model is divergent in the number and type of stages to the Rogers (1962) model, two key similarities exist. Firstly, the ability of the adopting unit to skip stages, and secondly, both models allow for rejection to occur at any stage throughout the adoption process.

Another key innovation diffusion model was developed by Reid (1981). In contrast to the aforementioned consumer orientated models, this innovation diffusion model is tailored to the internationalisation process. Specifically, Reid (1981) conceptualised the export expansion process as a five-stage model of export awareness, intention, trial, evaluation, and acceptance (Table 2). In developing this model, Reid determined that it had to overcome two key limitations. Firstly, he indicated that the model must clearly identify its applicability to SMEs, since decision makers in SMEs are less bound to the structural arrangements that can be found in larger firms. Secondly, he highlighted that any study examining export decisions had to play close attention to the role of the decision maker in the export expansion process. Elaborating on the model's functionality, Reid proposed that it was plausible that the stages could occur systematically. This point is in some ways similar to the argument put forward by Rogers (1962) that whilst stages can be compressed together, they nonetheless occur.

\section{Insert Table 2- here}

Lim et al. (1991) further sought to establish the validity of the innovation diffusion model by empirically testing a four-stage model of export adoption (awareness, interest, intention, and adoption). The model was developed through the integration of works from the schools of consumer behaviour (i.e., Robertson, 1971; Harvey, 1979) and international marketing (i.e., Reid, 1981). The synthesis of these models was important to allow for a construct of interest, that was omitted from the Reid (1981) model, to be reintroduced. This provided a model that recognised the stage in which the managerial team became favourably disposed to the innovation of exporting. A difference between the Lim et al. (1991) model and the models of Reid (1981) and Robertson (1971) is the absence of the 'Trial' stage. In the Lim et al. (1991) model, the existence of a trial stage was acknowledged; however, it was excluded from the study due to the difficulties in demonstrating a trial of exporting. An important attribute of the Lim et al. (1991) model is the ability of firms to skip stages. This is demonstrated by the possible movements from awareness to intention and adoption, and the additional movement from interest to adoption. This concept brought the model back into line with the original works of Rogers (1962) and Robertson (1971) by highlighting the possibility of circumventing stages (Leonidou \& Katsikeas, 1996).

The study by Wickramasekera and Oczkowski (2006) added to the internationalisation literature by developing a scale to measure the internationalisation process of Australian wineries. A four stage synthesised model was developed utilising key innovation diffusion models from the literature, including Robertson (1971), Bilkey and Tesar (1977), Cavusgil (1980), Reid (1981), and Schiffman and Kanuk (1991). The model excluded the stages representing de-internationalisation, as proposed in the models by Czinkota (1982) and Crick (1995), due to the overall strength of Australian wineries in the international marketplace and subsequently, the low likelihood of de-internationalisation. Another important characteristic of the model was the inclusion of the trial stage, which was omitted from the model by Lim et al. (1991). In line with calls from Sullivan (1994), the stages were measured using multi-item scales.

However, Sullivan's (1994) measures for internationalisation were not used as these measures would have provided a score of zero for non-exporting firms. Instead, based on suggestions by Ramaswamy, Kroeck and Renforth (1996), psychometric measures were used. This is also in accordance with the study conducted by Lim et al. (1991), in which the four stages of the export adoption model were measured using psychometric measures. The development of a scale to measure the degree of export development provided a clear and scientifically valid means of delineating between the stages of the theoretical innovation diffusion model proposed in the study (Andersen, 1993). Further empirical testing of this scale also highlighted its validity in an operational sense (Andersen, 1993; Leonidou \& Katsikeas, 1996). Despite this, a key limitation of the study conducted by Wickramasekera and Oczkowski (2006) is the merging of the 'Evaluation' and 'Trial' stages into a singular stage. This means that firms conducting a mental analysis of exporting are considered to have the same characteristics as firms that have commenced exporting and are learning from the process. This study overcomes this limitation by splitting the trial stage into two stages. 


\subsection{Proposed Model of Export Adoption}

A five stage synthesised model of export adoption was developed through a synthesis of the key innovation diffusion models from the consumer behaviour and internationalisation schools (Figure 1). Although the models from internationalisation literature have advanced our understanding of the internationalisation process, they have been limited by exclusion of some key concepts of the innovation diffusion models. Through integrating elements of the schools of thought (Uppsala Model and the innovation adoption models), the richness of the model itself can be improved, particularly by ensuring the salient features of the initial innovation diffusion model by Rogers (1962) are not neglected in re-evaluation. The structure of the model itself is a full reflection of the model proposed by Rogers (1962) in terms of the stages used. The model is also similar to the one proposed by Wickramasekera and Oczkowski (2006), however, it includes the key stage 'Evaluation' which was excluded from their model. The inclusion of this stage is seen as important since it highlights the decision the firm makes to properly analyse any exporting efforts before expanding further upon these efforts. Furthermore, it is also consistent with the earlier models developed by Rogers (1962) and Reid (1981).

Insert Figure 1- here

The definitions for the five stages of the proposed model (Figure 1) are provided below:

- Awareness: Adoption unit is aware of exporting as an opportunity; however, lacks the motivation to pursue exporting further at this stage (Lim et al., 1991; Rogers, 1962; Wickramasekera \& Oczkowski, 2006).

- Interest: Adoption unit has a positive disposition towards exporting (Lim et al., 1991; Robertson, 1971; Rogers, 1962).

- Evaluation: The adoption unit undertakes a mental trial of exporting to determine possible benefits before committing to an actual trial (Robertson, 1971; Rogers, 1962).

- Trial: The firm exports on a small scale to determine the benefits of exporting (Reid, 1981; Robertson, 1971; Rogers, 1962).

- Adoption: Adoption unit views exporting favourably and continues to export (Reid, 1981; Rogers, 1962).

The dotted lines in the model (Figure 1) signify the ability of the firm to skip stages as was highlighted in the seminal models developed by Rogers (1962) and Robertson (1971), and also shown in the study conducted by Lim et al. (1991).

\section{Objectives of the study}

To test the effectiveness of the proposed five stages synthesised model of export adoption in explaining export development by examining the following propositions:

Proposition 1. There is an emerging tendency for firms in the Queensland Food and Beverage Industry to be INVS.

Proposition 2. The internationalisation of firms in the Queensland Food and Beverage Industry is consistent with the proposed five stage synthesised model of export adoption.

The following section provides detail on the methodology and sampling framework employed, along with an overview of the statistical techniques that were used to conduct the testing.

\section{Methodology}

The population of this study included all SMEs within the Queensland Food and Beverage Industry. Although there have been studies that have examined internationalisation in the food and beverage industry (Philp, 1998), a review of extant literature suggests that this is one of the first studies to conduct an in-depth examination of firm internationalisation in the Queensland Food and Beverage Industry. The Queensland Food and Beverage Industry has been extremely successful and is made up of an overwhelmingly large number of SMEs (Department of State Development, 2007). The selection of this industry was important for numerous reasons. Foremost, it is a traditional industry that has played a significant role in contributing to the export success of the Queensland economy. In particular, the industry has a high proportion of SMEs that are responsible for the majority of exports. In addition, a recent Austrade report also highlighted a higher incidence of INVs in this industry in comparison to other industries (Austrade, 2002). Lastly, the Queensland Food and Beverage Industry were chosen as it operates within a relatively homogenous economic and political environment, enabling a degree of experimental control. This study will specifically examine the internationalisation behaviour of SMEs in terms of export development. Accordingly, this study does not consider other possible modes of market expansion available to the firm (Leonidou \& Katsikeas, 1996). Nevertheless, focusing on exporting and the 
development process does allow for richer insights into what processes firms go through when deciding to export (Bilkey, 1978; Leonidou \& Katsikeas, 1996).

The research design of this study corresponds with the call from Fan and Phan (2007) to examine how the existing stage based models of firm internationalisation can explain the internationalisation process of INVs. This study examined the impact of a range of independent variables identified in the literature on export adoption. To do this, the study used a two stage research approach (Creswell, 2003). Firstly, we collected quantitative data using a questionnaire (survey instrument) developed from existing scales in the internationalisation literature. Subsequently, we collected qualitative data using telephone interviews. This process permitted for the statistical significance of the model to be highlighted, whilst allowing for a phenomenon of internationalisation to be explained and understood in greater detail (Creswell, 2003). This strategy was invaluable in this study since firms could be quantitatively classified into the stages of the innovation diffusion model, whilst qualitative data highlighted the transition of firms through the stages. Namely, this study used a questionnaire (survey instrument) and interviews to examine the five stage synthesised model of export adoption (Liamputtong \& Ezzy, 2005; Saunders, Lewis \& Thornhill, 2003). The unit of analysis in this study was the manager or the managerial team, and specifically, the manager that was most responsible for the decision to export or to make marketing decisions (Liamputtong \& Ezzy, 2005). We utilised the key informant technique to assist in the selection of individuals to participate in the study. The use of key informants is regarded as being an effective means of gaining representative views from the decision making units of firms (Mitchell, 1994; Seidler, 1974).

We established a database of 702 firms from a combination of sources, including: the Queensland Food Manufacturer Directory (Department of State Development, 2007), the Australian Suppliers Directory (Austrade, 2007), the Queensland Wineries and Regions List (Tourism Fair Trading and Wine Industry Development, 2006), and a general internet search for food and beverage firms. Data from the Australian Bureau of Statistics indicated that the current population of firms for the industry is approximately 1000 (Australian Bureau of Statistics, 2007). However, despite all reasonable attempts, this number was not obtained in the process of database development. The inability to reach the desired sample size can in part be attributed to the large number of firms that were no longer in operation. It could also be associated with the bias some of these sources have for exporting firms. In December 2007, all firms were contacted and invited to participate in the study. Of those contacted, 253 firms agreed to participate in the study, 334 declined, and 114 were unreachable or had shutdown. After three progressive mail outs via email and mail, a total of 79 useable responses were received. This provided a response rate of 11.25 percent. Mail and email surveys have been criticised for being subject to non-response bias. To reduce the impact of non-response bias the extrapolation method was used to check for potential bias (Armstrong \& Overton, 1977). In-depth interviews were subsequently conducted with key informants from firms, including firms that were identified as being INVs or had the potential to be INVs (Liamputtong \& Ezzy, 2005; Mitchell, 1994). Purposive sampling was used to select these firms (Saunders et al., 2003). Of note, Posdsakoff, MacKenzie, Lee and Podsakoff (2009) identified common method variance as a problem in behavioural research. Several methods have been proposed to avoid or correct common method variance. The best strategy is to avoid or minimise the potential for common method variance in the research design stage. We achieved this by using divergent sources of information for key variables, mixing the order of questions, and using different scale types.

\section{Data Analysis}

A review of statistical techniques was conducted to identify the most effective method of data analysis with which to examine the proposed model of export adoption. In part, this was governed by the number of responses received for this study.

To provide a better opportunity to analyse the data, all of the stages were collapsed into one of two groups. Firms in the 'Awareness', 'Interest', and 'Evaluation' stages were grouped into the 'Non-Exporter' group ( $\mathrm{N}=32$ ), whilst the firms in the 'Trial' and 'Adoption' stages were placed into the 'Exporter' group ( $\mathrm{N}=47)$. This provided 79 responses available for analysis. The use of a 'Non-Exporter' and 'Exporter' dichotomous classification of firms not only provides a means of increasing the number of firms for the dependent variable, but is also consistent with exporting literature (Burton \& Schlegelmilch, 1987; Leonidou, 1995; Philp, 1998; Sharkey, Lim \& Kim, 1989).

Statistical techniques that could analyse a dichotomous dependent variable were reviewed. It was found that binary logistic regression was the most effective and flexible method in comparison to other methods including ordinary least squares regression and discriminant analysis (Hair, 2006; Philp, 1998; Tabachnick \& Fidell, 2007). Binary logistic regression was beneficial in this analysis since it is able to provide a direct estimation of whether 
a firm falls into one of the two proposed groups based on the parameter estimates of the identified predictors (Hair, 2006; Philp, 1998; Tabachnick \& Fidell, 2007). Specifically, it is able to highlight the probability of a firm being an 'Exporter' or a 'Non-Exporter' from the parameter estimates of the model. In addition to this, the method was capable of indicating the level of significance each independent variable had on the predictive ability of the model (Tabachnick \& Fidell, 2007).

The analysis was conducted in a backward stepwise manner as this technique identifies relationships where a suppressor effect may be in place (Menard, 2002). Nonetheless, a key issue with using this analysis was that it was unable to theoretically test the proposed model of export adoption as initially intended. This change in the direction of the analysis was a consequence of the reclassification of firms into the two groups: 'Exporter' and 'Non-Exporter'. Accordingly, this analysis was only effective in determining which set of predictors were the most effective in explaining the phenomenon of a transition from not exporting to exporting. The analysis did, however, indicate potential misclassifications of firms that are currently 'Non-Exporters', but were predicted to be 'Exporters', and vice versa. These misclassifications allowed for the identification of a set of firms where follow-up interviews were conducted to provide insights into whether the stage based approach could explain the INV internationalisation process.

The final model developed for this study is seen to achieve the central criteria of model development as outlined by Hosmer and Lemeshow (2000). That is, 'the goal of any method of model development is to select those variables that result in a "best" model within the scientific context of the problem (Hosmer \& Lemeshow, 2000, p. 91). In saying this, the development of the model had to strike a balance between two key goals. On the one hand the model had to be parsimonious and succinct, and on the other hand, it had to be theoretically plausible (Hosmer \& Lemeshow, 1989). In addition, the objective of this study was not to create a model with the highest explanatory and predictive power of the exporting process. Rather, the objective was to explain INV internationalisation with the proposed Five Stage Synthesised Model of Export Adoption. Accordingly, the model was designed to be simple, whilst still being rich from a theoretical standpoint. Rigorous testing of model fit was conducted using the Likelihood Ratio Test (-2LL), however, this test removed numerous variables that accounted for a high degree of the model's theoretical richness. As such, the retention of these variables is considered an acceptable practice by Hosmer and Lemeshow (2000) owing to their theoretical importance.

The final model was capable of predicting the overall probability that a firm was an 'Exporter' or a 'Non-Exporter' with an 84.8 percent success rate. This was an improvement from the proposed model, which lacked the independent variables and predicted overall exporting status with a 59.5 percent success rate. The model was found to be valid with a highly significant Chi-Square value ( $\mathrm{p}=0.000$ with 9 degrees of freedom) (Hair, 2006). Similarly, the results of the Hosmer and Lemeshow Goodness of Fit Test indicated that the model had an overall good fit (with a Chi-Square value of 4.525, which was found to be non-significant at 0.807) (Tabachnick \& Fidell, 2007). The Classification Histogram of Observed Groups and Predicted Probabilities, shown in Figure 2, show a relatively good concentration of firms at both poles, although it would appear that there is greater potential to identify 'Exporters'. Equally important are the results of the Classification Table of Observed Groups and Predicted Probabilities (Table 3). The results indicate that the final model only misclassified 12 firms in total.

\section{Insert Figure 2- here}

Insert Table 3- here

Although the final results could not directly provide support for the proposed Five Stage Synthesised Model of Export Adoption, the use of follow up interviews on misclassified firms from the logical regression model, and the selection of INVs/potential INVs from the initial dataset, did provide an avenue to evaluate the research propositions. The following will examine the export development process of a group of such firms. This discussion will examine their internationalisation process by comparing their internationalisation experiences (drawn from the questionnaire and follow up interviews) against the export adoption model proposed in this article. Where firms were misclassified by the logistic regression analysis, the results of the questionnaire and interview will be used to provide insights into why this occurred. The aim of this section is to report on the evaluation of the research propositions for study.

\section{Findings and Discussion}

\subsection{Is there Evidence of INVs in the Queensland Food and Beverage Industry?}

The results of this research indicate that there are INVs within the Queensland Food and Beverage Industry. The results relating to the length of time that firms had been in the industry were compared against the proposed Five 
Stage Synthesised Model of Export Adoption. Out of the 79 firms that participated in this study, 5 of these indicated that they had fully adopted exporting within a six year period since their inception. Based on the definition utilised in this study and in the INV literature (i.e. Oviatt \& McDougall, 1997), these firms could be classified as INVs. Importantly, this finding provides support for the notion that the existence of INVs is not strictly limited to the high technology sector as cited in extant literature (i.e., Bell, 1995; Jones, 1999; Knight \& Cavusgil, 1996; Oviatt \& McDougall, 1994).

\subsection{Is there an Emerging Tendency for Firms in the Queensland Food and Beverage Industry to be INVs?}

The results of the interviews conducted for this study highlight that rapid internationalisation is occurring in the Queensland Food and Beverage Industry. There are two key drivers of this trend in the industry. Firstly, the need to diversify from the Australian market to spread risk:

\section{'Exporting allows us to diversify our client base and to reduce risk, and to expose us to more growth.'}

Secondly, the characteristics of the products produced by the firms in terms of quality and cost:

'We produce high quality boutique wine...it's hard to get... we only produce 6000 cases.'

These results are consistent with the literature examining the INV phenomenon. In particular, the studies propose that unique and innovative products are a major factor driving internationalisation (Madsen and Servais, 1997). Another significant point supporting the notion that firms in the Queensland Food and Beverage Industry internationalise quickly arose in the interviews. Specifically, one informant stressed that the industry is globally oriented. The globalisation of industries is a factor that has previously been highlighted as a key contributor to the existence of INVs (Knight and Cavusgil, 1996; Rialp et al., 2005). In light of this, this factor may continue to play an important role in driving rapid international expansion in the industry in the coming years. Finally, the fact that in many cases the decision to export stemmed from firms being approached to export goods relatively soon after start up could indicate that this trend is set to continue.

\subsection{Is the Internationalisation of INVs consistent with the Proposed Five Stage Synthesised Model of Export Adoption?}

Through the evidence gathered via the interviews, it was possible to determine that firms did progress through a stage based approach to internationalisation as outlined in the Five Stage Synthesised Model of Export Adoption (Lim et al., 1991; Rogers, 1962). All firms in the study were 'aware' and 'interested' in exporting. The decision to export did occur in line with an 'evaluation' of the potential benefits and costs of exporting (Rogers, 1962). This 'Evaluation' stage encompassed a continuum from a general overview of exporting to a specific evaluation of export markets. Finally, there was support for a trial of exporting; however, this 'Trial' stage was unnecessary in two cases due to the informant's prior experience:

'It was important that I already had experience in exporting, so we didn't hesitate. It's not like we had to worry and do years of research and get the right business partners...it was a no brainer. I knew how to get shipping companies to load goods on a container and how to insure them, and do all the paperwork.'

This in itself provided an additional finding that was extremely significant to this research: firms do have the ability to skip stages as outlined in the seminal works of Rogers (1962) and Robertson (1971).

The main objective of this research is to find an appropriate theoretical framework to explain the internationalisation process of INVs. Past literature indicated that stage models were incapable of explaining the existence of INVs (Knight \& Cavusgil, 1996; Oviatt \& McDougall, 1994, 1997). This was due to the supposed deterministic and incremental nature of the models that resulted in the firm internationalising in a slow, gradual manner long after being established in the domestic market (Andersson \& Wictor, 2003; Chetty \& Campbell-Hunt, 2004; Rialp et al., 2005). However, in formulating these arguments many scholars argued against the Uppsala Model, and by implication, their comments impacted upon the innovation adoption models. This was without any consideration of the key salient features of the innovation diffusion model that set it apart from the Uppsala Model (Wickramasekera \& Oczkowski, 2004).

The innovation diffusion model is not bound by a need to follow stages or a deterministic and incremental sequential pattern. In the seminal work conducted by Robertson (1971), he indicated that in the innovation adoption process, there was no specified sequence of stages that had to be followed. Earlier, Rogers (1962) indicated that the decision-maker could skip stages. These features clearly indicate that the innovation diffusion model does not have the deterministic structured design that would have made it incapable of explaining rapid internationalisation. The existing models of export development advanced our understanding of firm internationalisation. However, they were limited by the fact that not all of the models incorporated the dynamic 
nature of the innovation diffusion model. Accordingly, this study re-evaluated the models of export development to develop a synthesised model of export adoption that captures the richness of the original models.

In reflecting on the results of this study, although the data from the questionnaires could not be used to directly test the synthesised model of export adoption, the responses obtained from the interviews, based on misclassified firms from the logistic regression analysis and INVs/Potential INVs, did provide strong support for the case that firm internationalisation can be explained by the proposed model. Generally the firms did move through the stages of the proposed model of export adoption (Lim et al., 1991; Reid, 1981; Robertson, 1971; Rogers, 1962). All firms interviewed were 'aware' of exporting at one point in their establishment, however, some 'Non-exporters' lacked the 'interest' to seek more information (Lim et al., 1991; Rogers, 1962). The fact that some firms classified themselves as 'interested' in exporting indicates that firms do shift from 'awareness' to 'interest' before conducting a proper 'evaluation' of exporting (Lim et al., 1991; Robertson, 1971; Rogers, 1962). All firms interviewed indicated that at some point they sought information relating to exporting to 'evaluate' what was involved (Robertson, 1971; Rogers, 1962). Such avenues for this information included: seminars, Austrade, contacts in the Government, potential customers, or information on the Internet. In some instances, firms indicated that they exported on a limited scale to allow them to determine the benefits of exporting, much like a 'trial'. Although in two cases there was a digression from the 'Interest' stage straight to 'Adoption' stage of exporting. This confirmed one of the proposed paths for stage skipping illustrated in Figure 3. The ability of the firms to skip stages in both instances was made possible through the key informant's previous experiences (Robertson, 1971; Rogers, 1962). The fact that there was evidence of skipping stages reiterates the point that the innovation diffusion model is dynamic, where the decision maker is not bounded by the need to develop in an incremental sequential manner (Robertson, 1971; Rogers, 1962).

Insert Figure 3- here

Overall, based on the interview results, it is apparent that the internationalisation of firms within the Queensland Food and Beverage Industry, including INVs is consistent with the Five Stage Synthesised Model of Export Adoption. The results of this analysis indicate that the Five Stage Synthesised Model of Export Adoption presents a solution for explaining the rapid internationalisation of INVs. The model was shown not to be limited by deterministic incremental sequential aspects in explaining the internationalisation process of INVs, as has been suggested in the literature (Knight \& Cavusgil 1996; Oviatt \& McDougall 1994, 1997). Instead, the results of this analysis indicated that the model could be quite flexible, as it can adapt to the experiences of the decision maker as was initially postulated in the innovation adoption models developed by Rogers (1962) and Robertson (1971). From a broader perspective, the model is also quite effective for explaining other cases where firms did not have prior experience at their disposal. Therefore, based on the results of this analysis, it can be concluded that the Five Stage Synthesised Model of Export Adoption presented in this study is an appropriate theoretical framework for explaining the INV internationalisation process.

\section{Limitations and directions for future research}

The literature on INV internationalisation has suggested that stage models are incapable of explaining the internationalisation of INVs due to the incremental sequential nature of the models. This research has shown that the innovation diffusion model is not bound by the limitations indicated within the literature and can be used as an effective theoretically grounded framework for explaining the internationalisation process of INVs.

In addition to the above, this research has also shown that some firms have been able to accelerate their internationalisation, often through the prior learning, experience, networking, and management skills of the management team. These enterprises experience the stages described in the stage based models by acquiring exporting skills in different ways to traditional exporters and are able to progress through these stages at a faster rate. These findings reflect those in other studies. While some firms are 'new' in terms of the time since their establishment as legal entities, they are often much 'older' in terms of the length and variety of experience of their owners and/or managers (Argyrous, 1993, 2000).

While the focus of this paper is on providing a theoretical explanation for the INVs, the results of the study also provide valuable insights into policy implications. Governments and export promotion agencies laud rapid internationalisation due to the multitude of benefits exports bring to the country and to the regions where the firms are located. However, if there is a downturn overseas, many INVs may suffer because they lack a presence in the domestic market which would allow them to obtain sufficient profits to survive. The findings by Argyrous (2000) suggest that, owing to the fact that many of the Born Globals identified in the AMC/McKinsey Report (1993) did not weather the Asian Crisis well, rapid internationalisation can lead to potential difficulties when there are economic downturns. Therefore, in terms of policy implications, the role of business advisory 
organisations such as regional development boards may be to suggest that firms develop a greater presence in the domestic market before considering exporting. In addition, the proposed model could be adapted to provide a probability value of the export readiness of a firm based on completing a brief questionnaire. Those receiving a higher probability value should be encouraged / assisted to export, whilst those receiving a lower value should be provided appropriate assistance in developing their general business skills. The interviews confirm the value of these policies and indicate the importance of drawing attention to the management skills and attributes needed for successful exporting.

In terms of limitations, this study focuses on the Queensland Food and Beverage Industry. Despite the numerous benefits of focusing on this single industry, it does affect the ability to generalise the results. Accordingly, the results of this analysis have limited applicability to other industries. Furthermore, in future studies it would be beneficial to examine the export development model using a technique such as Structural Equation Modelling (SEM), as it explicitly recognises measurement error and allows for the simultaneous examination of all relationships in the model using a larger sample (Tabachnick \& Fidell, 2007). This will provide more conclusive statistical evidence that firms do move through the five stages of the synthesised model. Moreover, the scope of this study has been confined to market expansion of SMEs in terms of exporting, due to the theoretical and economic benefits associated with exports. However, the specific focus on the mode of exporting has meant that this study has not considered other possible international entry modes available to the firm (Calof \& Beamish, 1995 ) and the focus on SMEs has meant that the model has limitations in explaining the internationalisation of large firms.

\section{References}

Andersen, O. (1993). On the internationalization process of firms: A critical analysis. Journal of International Business Studies, 24(2), 209-251. http://dx.doi.org/10.1057/palgrave.jibs.8490230

Andersson, S., \& Wictor, I. (2003). Innovative internationalisation in new firms: Born Globals - the Swedish case. Journal of International Entrepreneurship, 1(3), 249-275. http://dx.doi.org/10.1023/A:1024110806241

Argyrous, G. (1993). Emerging exporters: An evaluation. Journal of Australian Political Economy, 32(December), 106-126.

Argyrous, G. (2000). The high road and the low road to international trade: Emerging exporters revisited. Journal of Australian Political Economy, 45(June), 46-67.

Armstrong, J. S., \& Overton, T. S. (1977). Estimating non-response bias in mail surveys. Journal of Marketing Research, 14(3), 396-402. http://dx.doi.org/10.2307/3150783

Austrade. (2002). Knowing and growing the exporter community. [Online] Available: http:///www.austrade.com (May 12, 2007)

Austrade. (2007). Australian suppliers directory. [Online] Available: http:///www.austrade.com (May 12, 2007)

Australian Bureau of Statistics. (2007). Counts of Australian businesses, including entries and exits, Australia June to June: Australian Bureau of Statistics. [Online] Available: http://www.abs.gov.au/ausstats/abs@.nsf/cat/8165.0 (April 23, 2008)

Bell, J. (1995). The internationalization of small computer software firms: A further challenge to 'stage' theories. European Journal of Marketing, 29(8), 60-75. http://dx.doi.org/10.1108/03090569510097556

Bilkey, W. J. (1978). An attempted integration of the literature on the export behaviour of firms. Journal of International Business Studies, 9(1), 33-46. http://dx.doi.org/10.1057/palgrave.jibs.8490649

Bilkey, W. J., \& Tesar, G. (1977). The export behaviour of smaller-sized Wisconsin manufacturing firms. Journal of International Business Studies, 8(1), 93-99. http://dx.doi.org/10.1057/palgrave.jibs.8490783

Burton, F. N., \& Schlegelmilch, B. B. (1987). Profile analyses of non-exporters versus exporters grouped by export involvement. Management International Review, 27(1), 38-49.

Calof, J. L., \& Beamish, P. W. (1995). Adapting to foreign markets: Explaining internationalization. International Business Review, 4(2), 115-131. http://dx.doi.org/10.1016/0969-5931(95)00001-G

Cavusgil, S. T. (1980). On the internationalisation process of firms. European Research, 8(6), 273-281.

Chetty, S. K., \& Campbell-Hunt, C. (2004). A strategic approach to internationalization: A traditional versus a 'Born-Global' approach. Journal of International Marketing, 12(1), 57-81. http://dx.doi.org/10.1509/jimk.12.1.57.25651 
Chetty, S. K., \& Hamilton, R. T. (1996). The process of exporting in owner-controlled firms. International Small Business Journal, 14(2), 12-25. http://dx.doi.org/10.1177/0266242696142001

Clark, T., Pugh, D. S., \& Mallory, G. (1997). The process of internationalization in the operating firm. International Business Review, 6(6), 605-623. http://dx.doi.org/10.1016/S0969-5931(97)00034-6

Coviello, N. E., \& McAuley, A. (1999). Internationalisation and the smaller firm: A review of contemporary empirical research. Management International Review, 39(3), 223-256.

Creswell, J. W. (2003). Research design: Qualitative, quantitative, and mixed method approaches (2nd ed.). California: Sage Publications.

Crick, D. (1995). An investigation into the targeting of UK export assistance. European Journal of Marketing, 29(8), 76-94. http://dx.doi.org/10.1108/03090569510097565

Czinkota, M. R. (1982). Export development strategies: U.S. promotion policy. New York: Praeger.

Department of Foreign Affairs and Trade. (2008). Benefits of trade. [Online] Available: http://www.dfat.gov.au/trade/benefits/ (April 21, 2008)

Department of State Development. (2007). Food processing and supply: Department of State Development. [Online] Available: http://www.sd.qld.gov.au/dsdweb/v3/guis/templates/content/gui_cue_cntnhtml.cfm?id=1092 (April 20, 2007)

Fan, T., \& Phan, P. (2007). International New Ventures: Revisiting the influences behind the 'born-global' firm. Journal of International Business Studies, 38(7), 1113-1131. http://dx.doi.org/10.1057/palgrave.jibs.8400308

Hair, J. F. (2006). Multivariate data analysis (6th ed.). Upper Saddle River: Pearson Prentice Hall.

Harvey, J. W. (1979). Evaluative conflict and information search in the adoption process. Advances in Consumer Research, 6, 209-213.

Hosmer, D. W., \& Lemeshow, S. (1989). Applied logistic regression. New York: Wiley.

Hosmer, D. W., \& Lemeshow, S. (2000). Applied logistic regression (2nd ed.). New York: Wiley. http://dx.doi.org/10.1002/0471722146

Jones, M. V. (1999). The internationalization of small high-technology firms. Journal of International Marketing, 7(4), 15-41.

Knight, G. A., \& Cavusgil, S. T. (1996). The born global firm: A challenge to traditional internationalization theory. Advances in International Marketing, 8, 11-26.

Leonidou, L. C. (1995). Export barriers: Non-exporters' perceptions. International Marketing Review, 12(1), 4-25. http://dx.doi.org/10.1108/02651339510080070

Leonidou, L. C., \& Katsikeas, C. S. (1996). The export development process: An integrative review of empirical models. Journal of International Business Studies, 27(3), 517-550. http://dx.doi.org/10.1057/palgrave.jibs.8490846

Liamputtong, P., \& Ezzy, D. (2005). Qualitative research methods (2nd ed.). South Melbourne: Oxford University Press.

Lim, J., Sharkey, T. W., \& Kim, K. L. (1991). An empirical test of an export adoption model. Management International Review, 31(1), 51-61.

Madsen, T. K., \& Servais, P. (1997). The internationalization of Born Globals: An evolutionary process? International Business Review, 6(6), 561-583. http://dx.doi.org/10.1016/S0969-5931(97)00032-2

Menard, S. W. (2002). Applied logistic regression analysis (2nd ed.). Thousand Oaks, California: Sage Publications.

Mitchell, V. (1994). Using industrial key informants: Some guidelines. Journal of the Market Research Society, $36(2), 139-145$.

Oviatt, B. M., \& McDougall, P. P. (1994). Toward a theory of International New Ventures. Journal of International Business Studies, 25(1), 45-64. http://dx.doi.org/10.1057/palgrave.jibs.8490193

Oviatt, B. M., \& McDougall, P. P. (1997). Challenges for internationalization process theory: The case of International New Ventures. Management International Review, 37(2), 85-99.

Philp, N. E. (1998). The export propensity of the very small enterprise (VSE). International Small Business 
Journal, 16(4), 79-93. http://dx.doi.org/10.1177/0266242698164005

Podsakoff, P., MacKenzie, S., Lee, J., \& Podsakoff, N. (2003). Common method biases in behavioral research: A critical review of the literature and recommended remedies. Journal of Applied Psychology, 88(5), 879-903. http://dx.doi.org/10.1037/0021-9010.88.5.879

Ramaswamy, K., Kroeck, K. G., \& Renforth, W. (1996). Measuring the degree of internationalization of a firm: A comment. Journal of International Business Studies, 27(1), 167-177. http://dx.doi.org/10.1057/palgrave.jibs.8490131

Reid, S. D. (1981). The decision-maker and export entry and expansion. Journal of International Business Studies, 12(2), 101-112. http://dx.doi.org/10.1057/palgrave.jibs.8490581

Rialp, A., Rialp, J., Urbano, D., \& Valliant, Y. (2005). The born-global phenomenon: A comparative case study $\begin{array}{lllll}\text { research. Journal of International Entrepreneurship, } & 3(2), & 133-171 .\end{array}$ http://dx.doi.org/10.1007/s10843-005-4202-7

Robertson, T. S. (1971). Innovative behavior and communication. London: Holt, Rinehart and Winston.

Rogers, E. M. (1962). Diffusion of innovations. New York: Free Press of Glencoe.

Saunders, M., Lewis, P., \& Thornhill, A. (2003). Research methods for business students (3rd ed.). London: Prentice Hall.

Schiffman, L. G., \& Kanuk, L. L. (1991). Consumer behaviour (4th ed.). New Jersey: Prentice-Hall.

Seidler, J. (1974). On using informants: A technique for collecting quantitative data and controlling measurement error in organization analysis. American Sociological Review, 39(6), 816-831. http://dx.doi.org/10.2307/2094155

Sharkey, T. W., Lim, J., \& Kim, K. L. (1989). Export development and perceived export barriers: An empirical analysis of small firms. Management International Review, 29(2), 33-40.

Sullivan, D. (1994). Measuring the degree of internationalization of a firm. Journal of International Business Studies, 25(2), 325-342. http://dx.doi.org/10.1057/palgrave.jibs.8490203

Tabachnick, B. G., \& Fidell, L. S. (2007). Using multivariate statistics (5th ed.). Boston: Pearson/Allyn \& Bacon.

Tourism Fair Trading and Wine Industry Development. (2006). Queensland wineries and regions. [Online] Available: http://www.dtftwid.qld.gov.au/wine/Wineries+and+Regions (June 20, 2007)

Wickramasekera, R., \& Oczkowski, E. (2004). Key determinants of the stage of internationalisation of Australian wineries. Asia Pacific Journal of Management, 21(4), 425-444. http://dx.doi.org/10.1023/B:APJM.0000048712.45272.6c

Wickramasekera, R., \& Oczkowski, E. (2006). Stage models re-visited: A measure of the stage of internationalisation of a firm. Management International Review, 46(1), 39-56. http://dx.doi.org/10.1007/s11575-007-0048-7

Table 1. Rogers' Innovation Adoption Model

\begin{tabular}{|l|l|l|}
\hline Stage & \multicolumn{1}{|c|}{ Behaviour Noted } & \multicolumn{1}{|c|}{ Function of Stage } \\
\hline Awareness & $\begin{array}{l}\text { Initial exposure of adopting unit to } \\
\text { innovation. Lack of complete information. }\end{array}$ & $\begin{array}{l}\text { Initiation stage for the adoption } \\
\text { process. }\end{array}$ \\
\hline Interest & $\begin{array}{l}\text { Adopting unit is now interested in } \\
\text { innovation and seeks further information. }\end{array}$ & $\begin{array}{l}\text { To increase the adopting units' } \\
\text { information regarding innovation. }\end{array}$ \\
\hline Evaluation & $\begin{array}{l}\text { Mental application of innovation to } \\
\text { present and future situation. }\end{array}$ & $\begin{array}{l}\text { To determine whether benefits of } \\
\text { adoption outweigh costs before trial. }\end{array}$ \\
\hline Trial & $\begin{array}{l}\text { Innovation is used on small scale to } \\
\text { determine its potential benefits. }\end{array}$ & $\begin{array}{l}\text { Testing of innovation in adopting } \\
\text { units'own situation before complete } \\
\text { adoption. }\end{array}$ \\
\hline Adoption & $\begin{array}{l}\text { Continued full use of innovation by } \\
\text { adopting unit. }\end{array}$ & Confirmation of trial results. \\
\hline
\end{tabular}

Source: (Rogers, 1962) 
Table 2. Export Behaviour as an Adoption of Innovation Process

\begin{tabular}{|c|c|c|c|c|c|}
\hline & Stage 1 & Stage 2 & Stage 3 & Stage 4 & Stage 5 \\
\hline & $\begin{array}{c}\text { Export } \\
\text { Awareness }\end{array}$ & $\begin{array}{c}\text { Export } \\
\text { Intention }\end{array}$ & Export Trial & $\begin{array}{c}\text { Export } \\
\text { Evaluation }\end{array}$ & Export Acceptance \\
\hline $\begin{array}{l}\text { Export } \\
\text { Adoption } \\
\text { Stages }\end{array}$ & $\begin{array}{l}\text { Problem or } \\
\text { opportunity } \\
\text { recognition, } \\
\text { arousal of need }\end{array}$ & $\begin{array}{l}\text { Motivation, } \\
\text { attitude, beliefs } \\
\text { and expectancy } \\
\text { about export } \\
\text { contribution }\end{array}$ & $\begin{array}{l}\text { Personal } \\
\text { experience } \\
\text { from limited } \\
\text { exporting }\end{array}$ & $\begin{array}{l}\text { Results from } \\
\text { engaging in } \\
\text { exporting }\end{array}$ & $\begin{array}{l}\text { Adoption of } \\
\text { exporting/rejection of } \\
\text { exporting }\end{array}$ \\
\hline $\begin{array}{l}\text { Decision } \\
\text { Maker } \\
\text { Variables } \\
\text { Involved }\end{array}$ & $\begin{array}{l}\text { Past experience } \\
\text { export related or } \\
\text { not; type, level } \\
\text { and amount of } \\
\text { foreign } \\
\text { information } \\
\text { exposed to, and } \\
\text { associated } \\
\text { individual } \\
\text { characteristics, } \\
\text { unsolicited } \\
\text { foreign orders }\end{array}$ & $\begin{array}{l}\text { Expectations } \\
\text { from entry into } \\
\text { foreign market, } \\
\text { foreign market } \\
\text { orientation, } \\
\text { export } \\
\text { orientation, and } \\
\text { underlying } \\
\text { attitudes toward } \\
\text { foreign } \\
\text { involvement }\end{array}$ & $\begin{array}{l}\text { Sought foreign } \\
\text { orders through } \\
\text { search of } \\
\text { foreign } \\
\text { markets }\end{array}$ & $\begin{array}{l}\text { Profitability, } \\
\text { sales } \\
\text { stability }\end{array}$ & $\begin{array}{l}\text { Export expansion } \\
\text { actively shown by } \\
\text { continued growth as: } \\
\text { (1) increased exports as } \\
\text { a percentage of sales; } \\
\text { (2) continued entry into } \\
\text { new markets; (3) } \\
\text { continued absolute } \\
\text { export growth; (4) } \\
\text { continued introduction } \\
\text { of new products into } \\
\text { export markets }\end{array}$ \\
\hline $\begin{array}{l}\text { Firm } \\
\text { Variables } \\
\text { Involved }\end{array}$ & $\begin{array}{l}\text { Past firm } \\
\text { performance, } \\
\text { reputation, and } \\
\text { visibility }\end{array}$ & $\begin{array}{l}\text { Managerial } \\
\text { goals and } \\
\text { existing firm } \\
\text { resources }\end{array}$ & $\begin{array}{l}\text { Unsolicited } \\
\text { foreign orders, } \\
\text { existence of } \\
\text { available } \\
\text { managerial } \\
\text { and financial } \\
\text { resources }\end{array}$ & $\begin{array}{l}\text { Results from } \\
\text { engaging in } \\
\text { export } \\
\text { behaviour }\end{array}$ & \\
\hline
\end{tabular}

Source: (Reid, 1981)

Table 3. Classification Table of Observed Groups and Predicted Probabilities

\begin{tabular}{|l|l|l|l|l|}
\hline \multicolumn{2}{|c|}{} & \multicolumn{3}{|c|}{ Predicted } \\
\cline { 3 - 5 } \multicolumn{2}{|c|}{} & Exporting Status & \\
\hline \multirow{3}{*}{ Observed } & Non-Exporter & Exporter & $\begin{array}{l}\text { Percentage } \\
\text { Correct }\end{array}$ \\
\hline \multirow{2}{*}{ Exporting Status } & Non-Exporter & 26 & 6 & 81.3 \\
\cline { 2 - 5 } & Exporter & 6 & 41 & 87.2 \\
\hline Overall Percentage & & & 84.8 \\
\hline
\end{tabular}

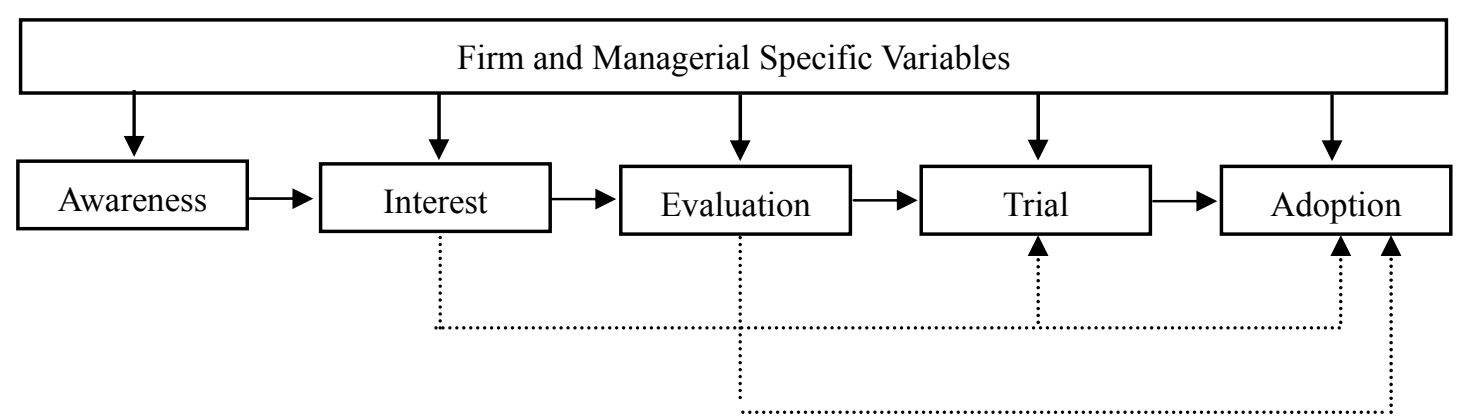

Figure 1. Five Stage Synthesised Model of Export Adoption

Source: (Lim et al., 1991; Reid, 1981; Robertson, 1971; Rogers, 1962; Wickramasekera \& Oczkowski 2006) 


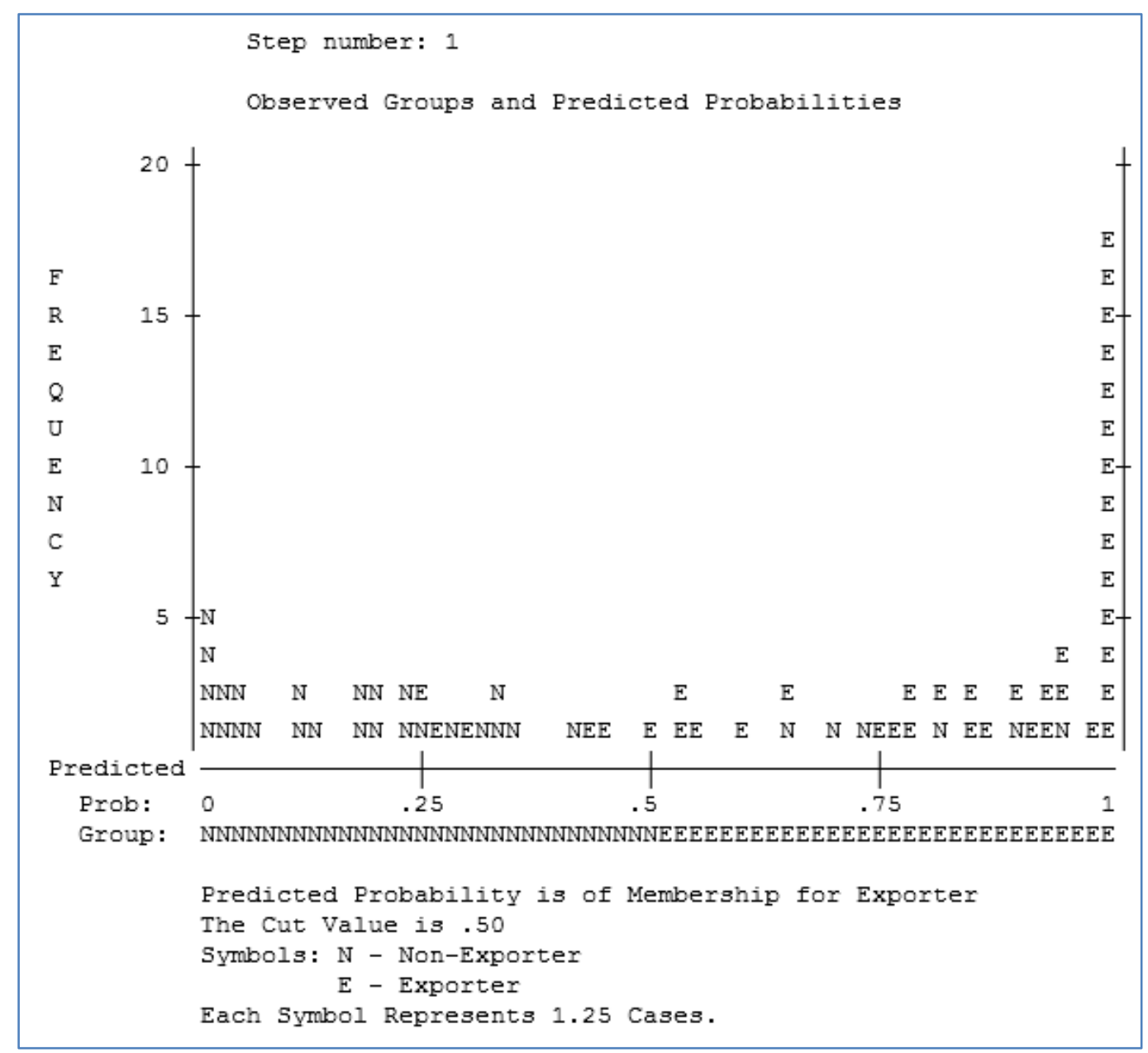

Figure 2. Classification Histogram of Observed Groups and Predicted Probabilities

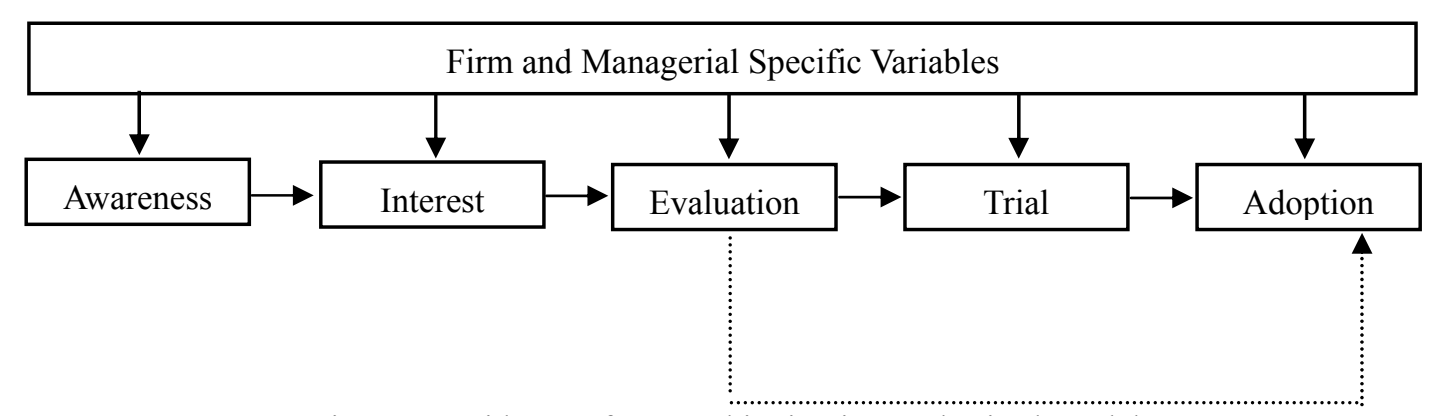

Figure 3. Evidence of Stage Skipping in Synthesised Model

Source: (Lim et al., 1991; Reid, 1981; Robertson, 1971; Rogers, 1962; Wickramasekera \& Oczkowski 2006) 